\title{
The Offer of Corporate Social Responsibility and Business Ethics Courses in University Accounting Undergraduate Programs: A Comparative Analysis among Administrative Sciences
}

\author{
Irene Buele Nugra ${ }^{1 *}$, Andrea Pesantez ${ }^{1}$ \\ ${ }^{1}$ Universidad Politecnica Salesiana, Ecuador \\ *Corresponding author: Irene Buele Nugra: ibuele@ups.edu.ec
}

\section{Abstract:}

Citation: Nugra I.B., Pesantez A. (2021) The Offer of Corporate Social Responsibility and Business Ethics Courses in University Accounting Undergraduate Programs: A Comparative Analysis among Administrative Sciences. Open Science Journal 6(2)

\section{Received: 23rd March 2021}

Accepted: $27^{\text {th }}$ May 2021

Published: $8^{\text {th }}$ July 2021

Copyright: (c) 2021 This is an open access article under the terms of the Creative Commons Attribution License, which permits unrestricted use, distribution, and reproduction in any medium, provided the original author and source are credited.

Funding: The author(s) received no specific funding for this work

Competing Interests: The author has declared that no competing interests exists.
Business failures in the 1980s, in the United States, have prompted the undergraduate programs of Business Administration, Public Administration, Foreign Trade, Accounting and Auditing, Economics, Finance, Management and Leadership, Human Talent Management, Transportation Management, Business Management, Marketing, International Business and Tourism to strengthen the techniques and processes of education of the future professionals, based on the teaching of social responsibility and ethics. Hence, the main purpose of this research is to analyze the presence of subjects related to Business Ethics and Corporate Social Responsibility (CSR) at Universities and Polytechnic Schools that are within the National Public and Private classification, and which receive allocations and revenues from the State in Ecuador. For this purpose, null hypotheses (Ho) and alternative hypotheses (H1) have been proposed, obtaining significant statistical evidence in the analysis of 89 curricula of administrative science programs. The analysis shows that the offer of the 47 studied subjects of social responsibility, and 75 of ethics does not depend on whether the university is public or private to receive allocations and revenues from the State, but it does depend on the type of program or degree that is being offered. These higher education subjects are important to help, the future professional, remember his or her correct behavior, commitment, and actions in the company, in society, and in the environment. 
Keywords: Administrative sciences, Accounting, Business ethics, Corporate social responsibility, Degrees.

\section{Introduction}

Concern for business ethics and corporate social responsibility (CSR) in the accounting and business profession emerged in the 1980s, in the United States. This is due to business failures (1) of great impact generated in this era, among them: Enron (2001), WorldCom (2002), Parmalat (2003), Lehman Brother (2008). These cases were the result of bad decisions made by their stakeholders, who violated the rules of social coexistence and showed negative professional ethical behavior. For that reason, Larrán and Andrade (2) have shown that the exclusively technical training offered to accounting professionals is not enough; thus, the need for CSR training was raised.

Therefore, ethics and social responsibility have become part of the university discussion agenda, and although the tendency to teach these topics has spread, the reality shows that the attempts have not been sufficient. This inefficiency is reflected in the global financial crisis of recent years, resulting in ethical misconduct in large companies and serious failures in regulatory and control policies (3).

The proper way of acting as a professional accountant, in a training process, has been implemented in the teaching of ethics and CSR. The word ethics is derived from the Greek word Ethos meaning custom or character, which implies that our actions and experiences in daily life are matters of ethics (4). On the other hand, CSR seeks to measure the impact of the activities of an organization, from the point of view of the intangible benefits that are involved in sustainable human development, and based on commitment, responsibility, and trust that the company creates for its employees (5).

To make higher education students put into practice the training of competent professionals, who can solve problems in a novel, in an efficient and effective way, is the main reason why universities are trying to disseminate issues of ethics and social responsibility (6). The ultimate objective is to professionally prepare a person in the development of personal competences and skills (7).

Through the research and review conducted to different documents, it is observed that social responsibility and business ethics have become, in recent years, one important aspect of managing a company (8). The International Federation of Accountants (IFAC) ensures the training and development of competences for the professional accounting program through standards and guidelines. The standards issued are called International Education Standards (IES); they prescribe professional knowledge, skills, values, ethical principles, and necessary attitudes that accounting professionals must comply with (1). Therefore, the application of the International Financial Reporting Standards (IFRS), directly compromises the ethics of the accountant in the preparation and presentation of financial statements. Similarly, Higher Education Institutions engage the educational process of Accounting and Auditing students around the demands and requirements of IFRS (9).

This research determines the supply of corporate social responsibility and business ethics courses offered by universities in the database of the Higher Education Council (CES) in Ecuador. It also analyzes the presence or inclusion of subjects related to business ethics and CSR through a review of the curricula 
or undergraduate academic grids of accounting programs in comparison with others regarding the administrative sciences.

\section{Materials and methods}

To achieve the objectives, the curricula and academic degree grids of the Universities and Polytechnic Schools that are within the National Public and Private classification, which receive allocations and revenues from the State, were downloaded from the database of the Council of Higher Education (CES). A total list of 31 Public Universities and Schools, and 10 Private Universities and Schools that receive allocations and revenues from the State was obtained.

Based on this information, the database was prepared based on the face-toface degree courses and, for the most part, on the redesigned curricula containing one or more subjects, such as ethics, business ethics, personal and professional ethics, personal and socio-environmental ethics, professional ethics, ethics and morals, as well as social responsibility, corporate social responsibility, business social responsibility, social, economic and financial responsibility. These subjects within undergraduate programs like Business Administration, Public Administration, Foreign Trade, Accounting and Auditing, Economics, Finance, Management and Leadership, Human Talent Management, Transportation Management, Business Management, Marketing, International Business and Tourism. A statistical sampling was then applied, where the total population of universities was 41 , with a confidence level of $90 \%$, and an accepted estimation error of $10 \%$, obtaining the optimal sample size of 24 universities, which is equivalent to 18 National Public Universities and Schools, and 6 Private Universities and Schools that receive allocations and revenues from the State.

To guarantee the analysis of the research, a null hypothesis (Ho) and an alternative hypothesis (H1) were generated, and the Statistical Product and Service Solutions (SPSS) program, which has data processing tools for statistical analysis (SPPSS Guide 15.0), was used, focusing on the Phi correlation coefficient, Pearson's Chi-square, Cramer's V and cross or contingency tables. It should be emphasized that for the statistical development, 0.05 was taken as the significance level, that is, a $5 \%$ risk probability, so if $\mathrm{p}>=0.05$, the Ho hypothesis is accepted and if $\mathrm{p}<=0.05, \mathrm{H} 1$ is accepted.

\section{Results}

The results are expressed in two sections: 1) Offering of corporate social responsibility and business ethics courses in universities. 2) Comparative analysis in accounting programs with others in the administrative sciences.

Proposal of subjects of corporate social responsibility and business ethics in universities.

This study analyzes 13 undergraduate programs classified within the administrative sciences, which provided an average result of 50 subjects offered in their curricula or academic grids. It is observed that 4 undergraduate programs exceed this total average; these are Business Management, Public Administration, Marketing and Transportation Management. The Business Management undergraduate program leads with 57 subjects. It is followed by Public Administration with 55 subjects. 


\begin{tabular}{|c|c|c|}
\hline \multicolumn{3}{|c|}{$\begin{array}{c}\text { Table } 1 \\
\text { UNDERGRADUATE PROGRAMS OFFERED ACCORDING TO UNIVERSITY TYPES }\end{array}$} \\
\hline Undergraduate Programs & \multicolumn{2}{|c|}{$\begin{array}{c}\text { Percentage of } \\
\text { Programs offered }\end{array}$} \\
\hline Business Administration & & $26 \%$ \\
\hline Private universities that receive state revenues and allocations & $26 \%$ & \\
\hline Public universities & $74 \%$ & \\
\hline Accounting and Auditing & & $17 \%$ \\
\hline Private universities that receive state revenues and allocations & $33 \%$ & \\
\hline Public universities & $67 \%$ & \\
\hline Tourism & & $12 \%$ \\
\hline Private universities that receive state revenues and allocations & $27 \%$ & \\
\hline Public universities & $73 \%$ & \\
\hline Economics & & $10 \%$ \\
\hline Private universities that receive state revenues and allocations & $44 \%$ & \\
\hline Public universities & $56 \%$ & \\
\hline Marketing & & $9 \%$ \\
\hline Private universities that receive state revenues and allocations & $25 \%$ & \\
\hline Public universities & $75 \%$ & \\
\hline International Trade & & $6 \%$ \\
\hline Public universities & $100 \%$ & \\
\hline Finance & & $6 \%$ \\
\hline Private universities that receive state revenues and allocations & $40 \%$ & \\
\hline Public universities & $60 \%$ & \\
\hline Public Administration & & $3 \%$ \\
\hline Public universities & $100 \%$ & \\
\hline Human Resource Management & & $2 \%$ \\
\hline Private universities that receive state revenues and allocations & $50 \%$ & \\
\hline Public universities & $50 \%$ & \\
\hline International Business & & $2 \%$ \\
\hline Private universities that receive state revenues and allocations & $50 \%$ & \\
\hline Public universities & $50 \%$ & \\
\hline Transporation Management & & $2 \%$ \\
\hline Private universities that receive state revenues and allocations & $50 \%$ & \\
\hline Public universities & $50 \%$ & \\
\hline Business Management & & $2 \%$ \\
\hline Public universities & $100 \%$ & \\
\hline Management and Leadership & & $2 \%$ \\
\hline Private universities that receive state revenues and allocations & $100 \%$ & \\
\hline Total universidades & & $100 \%$ \\
\hline
\end{tabular}


The Business Administration program, as shown, represents $26 \%$ of the total. In turn, $26 \%$ corresponds to Private Universities that receive state allocations and revenues. A $74 \%$ corresponds to National Public Universities, that is, 23 universities offer this program, which makes it the most offered program by Ecuadorian universities. The Tourism, Economics, Marketing and Finance programs are offered in greater proportion by the National Public Universities. The Public Administration, Business Management and International Trade programs are offered by all the National Public Universities or Polytechnic Schools. On the other hand, there is a balance in International Business, Human Resource Management and Transportation Management programs, which are offered both in the Universities and Polytechnic Schools that are classified as National Public and Private universities, which receive State allocations and revenues.

Universities and polytechnic schools, whether national public or private, that receive State allocations and revenues and offer degrees catalogued as Administrative Sciences, include CSR and Business Ethics as part of their academic curricula.

Based on this information, the following hypothesis are proposed:

Ho: The number of ethics and social responsibility subjects is independent from the type of University.

H1: The number of ethics and social responsibility subjects depends on the type of university.

\begin{tabular}{|c|c|c|c|c|c|}
\hline \multicolumn{6}{|c|}{$\begin{array}{c}\text { Table } 2 \\
\text { TYPE OF UNIVERSITY CROS }\end{array}$} \\
\hline & & & CSR & Ethics & Total \\
\hline & & & 1,00 & 2,00 & \\
\hline \multirow{4}{*}{ Type } & \multirow{2}{*}{\begin{tabular}{lr} 
Private & \multicolumn{2}{r}{ universities } \\
that receive & state \\
revenues & and \\
allocations &
\end{tabular}} & Count & 18 & 9 & 27 \\
\hline & & $\begin{array}{l}\% \text { of the } \\
\text { total }\end{array}$ & $20,2 \%$ & $10,1 \%$ & $30,3 \%$ \\
\hline & \multirow[t]{2}{*}{ Public Universities } & Count & 38 & 24 & 62 \\
\hline & & $\begin{array}{l}\% \text { of the } \\
\text { total }\end{array}$ & $42,7 \%$ & $27,0 \%$ & $69,7 \%$ \\
\hline \multirow{2}{*}{\multicolumn{2}{|c|}{ Total }} & Count & 56 & 33 & 89 \\
\hline & & $\begin{array}{l}\% \text { of the } \\
\text { total }\end{array}$ & $62,9 \%$ & $37,1 \%$ & $100,0 \%$ \\
\hline
\end{tabular}

\begin{tabular}{|c|c|c|c|}
\hline \multicolumn{3}{|c|}{ Table 3 } \\
\hline \multicolumn{2}{|c|}{ SYMMETRIC MEASUREMENTS } \\
\hline $\begin{array}{c}\text { Nominal } \\
\text { by } \\
\text { Nominal }\end{array}$ & Phi & 0,051 & 0,629 \\
\hline $\begin{array}{c}\text { Number of } \\
\text { valid cases }\end{array}$ & 89 & Approximate meaning \\
\hline \multicolumn{2}{|c|}{ Source: Authors' own elaboration } \\
\hline
\end{tabular}


Based on the Phi correlation coefficient, table 3 indicates a Phi value of 0.051 between the variables majors and subjects. It should be stated that the values should always be between 0 and 1 . Likewise, the approximate correlation is 0.629 , which means that this value is greater than 0.05 , which is the proposed significance $((0.629>0.05)$. This shows that there is no relationship between these variables, as shown in figure 1 . In other words, the null hypothesis (Ho) is not rejected, since it is evident that it does not matter the type of university, whether they are National Public or Private that receive State allocations and revenues regarding the offer of CSR and business ethics programs.

Comparative analysis of accounting degrees about other degrees in the Administrative Sciences

\begin{tabular}{|l|c|c|c|}
\hline \multicolumn{3}{|c|}{ Table 4 } \\
TOTAL SUBJECTS OF CORPORATE SOCIAL RESPONSIBILITY AND BUSINESS \\
ETHICS ACCORDING TO DEGREE PROGRAM
\end{tabular}

The Business Administration program has more business ethics and CSR subjects, with 15 and 19, respectively, out of the total of 1,148 subjects that make up the academic curricula of this program. On the other hand, the Accounting and Auditing program shows 12 business ethics subjects and 10 CSR subjects out of a total of 743 , representing $16 \%$ and $21 \%$ respectively.

Business ethics is divided into professional ethics, which represents $42 \%$ of subjects, pure ethics represents $25 \%$, and all subjects related to business ethics, ethics and morals, personal and socio-environmental ethics, and personal and professional ethics, each with a contribution of $8 \%$. Similarly, the CSR subject is classified in corporate social responsibility, with $40 \%$, corporate social responsibility with $30 \%$, social responsibility with $20 \%$ and all subjects related to social, economic, and financial responsibility with $10 \%$.

The Public Administration, International Business and Management, and Leadership programs do not offer any course on corporate social responsibility, 
and the Human Talent Management program does not offer any course on business ethics.

The following hypotheses are tested:

Ho: The offer of social responsibility and ethics courses does not depend on the degree program.

H1: The offer of social responsibility and ethics courses depends on the degree program.

\begin{tabular}{|l|c|c|c|c|}
\hline \multicolumn{5}{|c|}{ Table 5 } \\
& Value & df & $\begin{array}{l}\text { Asymptotic } \\
\text { (bilateral) }\end{array}$ & significance \\
\hline & $254,681 \mathrm{a}$ & 192 & & 0,002 \\
\hline Person's Chi-Square & 89 & & \\
\hline N. of valid cases & $\begin{array}{l}\text { CHI-SQRARE TESTS } \\
\text { minimum expected recount is .02. } \\
\text { Source: authors' own elaboration }\end{array}$ \\
\hline
\end{tabular}

\begin{tabular}{|c|c|c|c|}
\hline & YMMETR & $\begin{array}{l}\text { le } 6 \\
\mathrm{~L} \text { ME }\end{array}$ & JRES \\
\hline & & Value & $\begin{array}{c}\text { Approximate } \\
\text { significance }\end{array}$ \\
\hline $\begin{array}{l}\text { Nominal } \\
\text { per } \\
\text { Nominal }\end{array}$ & $\begin{array}{c}\text { Cramer's } \\
\mathrm{V}\end{array}$ & 0,488 & 0,002 \\
\hline N. of vali & cases & 89 & \\
\hline Source: a & ors' own & pration & \\
\hline
\end{tabular}

The Pearson's chi-square value is 254.681, with 192 degrees of freedom, which is the difference between (total rows - 1) and (total columns -1), as detailed in Table 5. Then for the analysis, the significance level of 0.002 is taken resulting lower than 0.05. Therefore, if $\mathrm{p}<=0.05 \mathrm{Ho}$ is rejected and H1 is accepted. This means that undergraduate programs depend on the offer of CSR and business ethics subjects. In addition, Cramer's V was used to verify that the strength of the ratio was about $48.8 \%$ as shown in Table 6 .

The diffusion of the subject Corporate Social Responsibility in the Administrative Sciences programs helps future professionals to address themselves in an adequate way, thinking about the welfare of the company, the environment and, above all, the society in general.

Ho: The subject of CSR is more relevant in the Accounting and Auditing program than in the other programs that make up the Administrative Sciences.

H1: The subject of CSR is more relevant in other programs that make up the Administrative Sciences than in the Accounting and Auditing program.

The CSR subject is exclusive to the Accounting and Auditing program because there is a $26.7 \%$ relationship when crossing the programs, and the subjects become qualitative variables. Therefore, Ho is accepted and $\mathrm{H} 1$ is 
rejected. On the other hand, the Business Administration program offers this subject in a percentage of $4.3 \%$.

Training, communicating, transmitting, and developing learning activities in the subject of social responsibility, offered by universities, helped, on a large scale, to make professionals aware of the damage caused to the environment, as a result of economic activity.

Ho: The subject of social responsibility will have a greater presence in the Accounting and Auditing program than in the Human Resource Management program.

H1: The social responsibility course will have a greater presence in the Human Resource Management program than in the Accounting and Auditing program

The Human Talent Management program offers this subject in a high value of $50 \%$. On the other hand, Accounting and Auditing offers social responsibility in $13.3 \%$, demonstrating, based on the results obtained in the cross table of qualitative variables, that the $\mathrm{H} 1$ (alternative hypothesis) is accepted.

In professional accounting life, behavior and making good decisions in difficult moments, intervene. For this reason, universities should teach subjects that build values to strengthen personal and business ethics.

Ho: The Accounting and Auditing program offers the business ethics subject.

H1: The Accounting and Auditing program does not offer the business ethics subject.

The subject of business ethics, in the academic grids, is offered in the same proportion, (50\%), both in the Accounting and Auditing program and in the other ones that make up the Administrative Sciences. Therefore, it is evident to reject $\mathrm{H} 1$ and accept Ho because the Accounting and Auditing program does offer, in $50 \%$, this subject.

\section{Discussion and conclusion}

In summary, 89 curricula were analyzed from 13-undergraduate programs, offered by 31 public universities and schools, and 10 private universities and schools that receive state allocations and revenues. It was also determined that, the average, in the academic curricula, is 50 subjects.

Consequently, Business Administration, with 26\%, is the program offered by most universities of Ecuador, that is, 23 universities. Something similar occurs with Accounting and Auditing, which occupies second place with 17\% (15 universities). In third place is Tourism with $12 \%$ (11 universities).

An important aspect is that the offer of studies in Ecuadorian universities is distributed approximately $70 \%$ for national public universities and $30 \%$ for private universities. The only exceptions are Public Administration, Business Management and Foreign Trade, which are offered in national public universities. On the other hand, private universities that receive allocations and revenues from the State are the only ones that offer Management and Leadership programs.

In conclusion, the comparative analysis shows that the 75 ethics subjects and 47 social responsibility subjects analyzed do not depend on whether the university is public or private, or whether they receive allocations and revenues 
from the State, but they do depend on the program offered. For example, Business Administration has 15 ethics subjects and 19 social responsibility subjects. Accounting and Auditing has 12 ethics and 10 social responsibility subjects, and Tourism has 11 ethics and 3 social responsibility subjects. Finally, Economics has 9 and 1, respectively.

Finally, the subjects were divided by categories to show that the CSR subject is offered, with greater strength, in the Accounting and Auditing program, becoming a subject of its own with $26.7 \%$. Likewise, the subject of corporate responsibility has more weight, with 52.2\%, for the Business Administration program. Similarly, the subject of ethics, as such, belongs, with $25 \%$, exclusively to Marketing. Therefore, Accounting and Auditing does offer the subject of business ethics at 50\%. A curious fact emerges from this approach: social responsibility is most strongly taught in the fourth cycle, while ethics is taught in the fifth cycle. However, according to the average, the two subjects mentioned above, should be part of the curriculum in the fifth cycle.

Additionally, it is concluded that this analysis contributes as a basis to promote the offer of these subjects in the administrative sciences programs, since it is very important to remind the future professional, based on theory, teachings, and experiences, how to act and how to maintain an adequate behavior in circumstances where the dignity of the professional is directly involved, in the management of a company, in the benefits of the stakeholders, or in the society.

\section{References}

1.Aldazabal, M. Ética y Responsabilidad Social en la Formación Superior Contable y Empresarial: Factores Determinanes. Tesis Doctoral. [revised 2015; cited 2019 Jul 25]. Available from https://addi.ehu.es/bitstream/handle/10810/15961/TESIS_ALDAZABAL_ETXEBARRIA_M\% 25AAEDURNE.pdf?sequence $=4 \&$ isAllowed $=\mathrm{n}$

2.Larrán M., Andrade F. La oferta de asignaturas de responsabilidad social corporativa y ética empresarial en las titulaciones de finanzas y contabilidad: análisis comparativo con el ámbito de la gestión de organizaciones. Revista De Contabilidad - Spanish Accounting Review. 2015:1-10. [cited 2019 Dec 15]. Availabe https://www.sciencedirect.com/science/article/pii/S1138489113000289

3.Gilli J., Schulman D., García N., Martinez A. www.saece.com. [revised 2016; cited 2019 Dec 25]. Available from http://www.saece.com.ar/docs/congreso5/trab099.pdf

4.Méndez C., Torres M., Camatón S. Importancia de la ética en la Educación Superior. Ciencias de la Educación. 2018; 4(2): 215 - 223. [cited 2019 Dec 15]. Available from https://dialnet.unirioja.es/descarga/articulo/6870906.pdf.

5.Martínez B., Gómez R. Los valores éticos en la responsabilidad social corporativa. Anagramas. 2015;14(28): 33-50. [cited $2019 \quad$ Dec 15]. Available from http://www.scielo.org.co/pdf/angr/v14n28/v14n28a02.pdf

6.Govea E., Vilela P., Vilela G. La ética profesional en la formación de los contadores y auditores para el control de la colusión. Revista Científica Retos de la Ciencia. 2018: 40 - 51. [cited 2019 Dec 15] Available from https://retosdelacienciaec.com/Revistas/index.php/retos/article/view/200

7.Briones E., Lara L. Educación ética en la Universidad a través del diálogo multicultural online. Revista Científica de Educomunicación. 2016: 99-107. [cited 2019 Dec 15]. Available from https://www.revistacomunicar.com/ojs/index.php/comunicar/article/view/C47-2016-10

8.School of International Studies. Plan Docente de la Asignatura Responsabilidad Social de las Organizaciones. [revised 2017; cited 2019 Nov 25]. Available from https://www.esci.upf.edu/uploads/imgen/2769-responsabilidad-social-de-las-organizaciones44311.pdf

9.Brijaldo M., Guerrero E. La Ética y Responsabilidad Social del Contador Público como aporte a la contrución de una mejor sociedad. Univerisidad de La Salle. 2017 [cited 2019 Dec 15]. Available from https: / ciencia.lasalle.edu.co/cgi/viewcontent.cgi?article $=1700 \&$ context=contaduria_publica 